\title{
COMPOSITION AND SEASONAL VARIATION OF FATTY ACIDS OF CHALCALBURNUS TARICHI IN VAN LAKE, TURKEY
}

\author{
Ozcan Baris Citil ${ }^{1}$, Ahmet Cihat Oner ${ }^{2}$ \\ ${ }^{1}$ Department of Animal Nutrition, Faculty of Veterinary, Selcuk University, Konya, Turkey \\ ${ }^{2}$ Department of Pharmacology and Toxicology, Faculty of Veterinary, Yuzuncu Yil University, Van, Turkey \\ ocitil@selcuk.edu.tr
}

\begin{abstract}
The seasonal variations of fatty acids compositions in the muscle lipids of Chalcalburnus tarichi in Van Lake were determined by using gas chromatography. Fish samples in two seasons (summer and winter) were obtained from Van Lake in Van, Turkey. The results obtained were subjected to statistical analyses by employing SPSS software and $p<0.05$ was accepted as significant value. The results showed that polyunsaturated fatty acids levels were found to be higher than those of monounsaturated fatty acids in two seasons. Palmitic and stearic acid levels in the muscles were the highest $(12.84 \%$ in summer and $31.06 \%$ in winter, respectively). Linoleic acid was the major PUFA in summer. Linoleic acid (C18:2 n6), docosahexaenoic acid (C22:6 n3), eicosapentaenoic acid (C20:5 n3), and arachidonic acid (C20:4 n6) were at the highest levels among the PUFAs. The percentages of total $\omega 3$ fatty acid were higher than those of total $\omega 6$ fatty acid in the fatty acid composition of Chalcalburnus tarichi in winter. Especially, in Chalcalburnus n-3/n-6 ratios which have nutritional importance for human health were $0.93 \%$ and $0.71 \%$ in winter and summer, respectively. In conclusion, seasonal variations and species differentiations affected fatty acid composition of Chalcalburnus tarichi in Van Lake.
\end{abstract}

Key words: fatty acid composition; seasonal variation; Chalcalburnus tarichi; Van Lake

\section{СОСТАВ И СЕЗОНСКИ ВАРИРАҢА НА МАСНИТЕ КИСЕЛИНИ KAJ CHALCALBURNUS TARICHI ВО EЗEРО ВАН, ТУРЦИЈА}

\begin{abstract}
Сезонските варирања на составот на масните киселини во мускулите на рибата Chalcalburnus tarichi во езерото Ван беа одредени со користење на гасна хроматографија. Примероци од риба беа земени од езерото Ван во Ван, Турција, во две сезони (лето и зима). Добиените резултати беа предмет на статистички анализи со помош на софтверот SPSS и вредноста $\mathrm{p}<0.05$ беше прифатена како карактеристична на рибата. Резултатите покажаа дека нивоата на полинезаситени масни киселини беа повисоки од оние на мононезаситени масни киселини во двете сезони. Нивоата на палмитинска и стеаринска кислеина во мускулите беа највисоки $(12.84 \%$ во лето и $31.06 \%$ во зима, соодветно). Линолната киселина беше главна полинезаситена масна киселина во лето. Линолна киселина (C18:2 n6), докозахексаеноинска кислеина (C22:6 n3), еикозапентаеноинска кислеина $(\mathrm{C} 20: 5 \mathrm{n} 3)$ и арашидонска киселина (C20:4 n6) беа на највисоко ниво меѓу полинезаситените масни киселини. Процентот на вкупни $\omega 3$ масни киселини кај Chalcalburnus tarichi беше повисок од вкупните $\omega 6$ масни киселини во вкупните масните кислини во зима. Особено, кај Chalcalburnus соодносот n-3/n-6, којшто има нутриционистичко значење за човековото здравје, беше со $0.93 \%$ и $0.71 \%$ во зима и лето, соодветно. Како заклучок, сезонските варирања и различноста на видот влијаат врз составот на масните киселини кај Chalcalburnus tarichi во езерото Ван.
\end{abstract}

Клучни зборови: состав на масни киселини; сезонски варирања; Chalcalburnus tarichi; езеро Ван

\section{INTRODUCTION}

Health benefits from the consumption of fish or fish oil may be related to polyunsaturated fatty acids (PUFAs) especially w-3 PUFAs (Sidhu,
2003). In recent years, this characteristic of fish has been widely researched. Previous studies reported that long-term, regular fish consumption, in other words w-3 PUFA intake, reduces the risk of contracting many diseases, such as cancer, lung 
diseases, Alzheimer and, in particular, cardiovascular diseases (Simopoulos, 1991; Cunquer, 2000).

The fatty acid composition of fish may vary depending on diet, temperature, season, type and geographical differences, salinity and spawning periods (Bandarra et al., 1997). Fatty acid composition differs between herbivorous, carnivorous and omnivorous fish species (Henderson and Tocher, 1987)

Van lake is the largest lake in is Turkey which is between the borders of the province of Van and Bitlis province, with east-west length of $70 \mathrm{~km}$, surface area of $3574 \mathrm{~km} 2$, the maximum depth of $451 \mathrm{~m}$ and the total volume of $607 \mathrm{~km} 3$, the world's largest soda lake and the fourth largest closed water basin. (Degens et al., 1978). Chalcalburnus tarichi live only in Van lake in Turkey. No reports have been published about the effects of seasonal variations on the fatty acid composition of Chalcalburnus tarichi in Van Lake. Considering these facts, it is believed that carrying out a systematic work on lipid profile of Chalcalburnus tarichi in this lake is necessary. The purpose of this study was to determine both the total fatty acid composition, and n-3/n-6 ratio variation of Chalcalburnus tarichi living in Van Lake.

\section{MATERIALS AND METHODS}

\subsection{Sample collection}

Chalcalburnus tarichi, used in this study, were obtained from Van Lake, Turkey. In the present study, the seasons chosen for analysis were summer and winter. The samples were collected in the middle month of each season during 2010 and 2011. Three individuals were sampled in each season. Fishes were transported in ice to the laboratory and dorsal muscle tissues were taken as the samples. The samples were frozen at $-26^{\circ} \mathrm{C}$ until analyzed. At the beginning of the analysis, the samples were allowed to equilibrate to room temperature.

\subsection{Fatty acid analysis}

In the extraction of fatty acids from the tissues studied, the basic method of Folch et al., (1957) was used for this, samples were homogenized in a chloroform/methanol (2/1, v/v) mixture.
Table 1

Effect of seasons on the total fatty acid composition (\%) of muscle lipids of Chalcalburnus tarichi ${ }^{A}$

\begin{tabular}{|c|c|c|}
\hline Fatty acids (\%) & Summer & Winter \\
\hline C 6:0 & $0.00 \pm 0.00$ & - \\
\hline C 8:0 & $0.01 \pm 0.00^{\mathrm{B}}$ & $0.00 \pm 0.00$ \\
\hline C $10: 0^{\mathrm{C}}$ & $0.02 \pm 0.01$ & $0.00 \pm 0.00$ \\
\hline C $12: 0$ & $0.12 \pm 0.03$ & $0.01 \pm 0.00$ \\
\hline C $14: 0$ & $2.45 \pm 0.06$ & $3.13 \pm 0.14$ \\
\hline C 15:0 & $0.28 \pm 0.04$ & $0.47 \pm 0.08$ \\
\hline C $16: 0$ & $12.84 \pm 0.12$ & $9.65 \pm 0.63$ \\
\hline C 17:0 & $0.86 \pm 0.07$ & $0.10 \pm 0.05$ \\
\hline C 18:0 & $26.13 \pm 0.75$ & $31.06 \pm 1.67$ \\
\hline C 20:0 & $0.74 \pm 0.02$ & $0.01 \pm 0.00$ \\
\hline C 21:0 & $0.36 \pm 0.07$ & $0.69 \pm 0.07$ \\
\hline C $22: 0$ & $0.47 \pm 0.00$ & $0.50 \pm 0.05$ \\
\hline C $24: 0$ & $1.12 \pm 0.10$ & $4.06 \pm 0.28$ \\
\hline$\Sigma \mathrm{SFA}^{\mathrm{D}}$ & $45.36 \pm 0.76$ & $50.57 \pm 1.91$ \\
\hline C $14: 1 n-5$ & $1.13 \pm 0.07$ & $1.98 \pm 0.04$ \\
\hline C $15: 1 n-5$ & $0.11 \pm 0.02$ & $0.27 \pm 0.01$ \\
\hline C $16: 1 n-7$ & $3.42 \pm 0.13$ & $6.76 \pm 0.39$ \\
\hline C $17: 1 n-8$ & $0.63 \pm 0.05$ & $0.60 \pm 0.03$ \\
\hline C $18: 1 n-9$ & $8.27 \pm 0.71$ & $8.74 \pm 0.26$ \\
\hline C $20: 1 n-9$ & $2.10 \pm 0.08$ & $1.89 \pm 0.08$ \\
\hline C $22: 1 n-9$ & $0.03 \pm 0.02$ & $0.07 \pm 0.01$ \\
\hline C $24: 1 n-9$ & $0.00 \pm 0.00$ & $0.00 \pm 0.00$ \\
\hline$\Sigma$ MUFA $^{\mathrm{D}}$ & $15.67 \pm 0.64$ & $20.29 \pm 0.20$ \\
\hline C $18: 2 n-6$ & $15.09 \pm 0.22$ & $11.94 \pm 0.92$ \\
\hline C $18: 3 n-3$ & $2.59 \pm 0.06$ & $1.40 \pm 0.12$ \\
\hline C $20: 2 n-6$ & $0.68 \pm 0.09$ & $0.42 \pm 0.04$ \\
\hline C $20: 4 n-6$ & $7.00 \pm 0.27$ & $1.87 \pm 0.15$ \\
\hline C $20: 5 n-3$ & $5.75 \pm 0.27$ & $4.46 \pm 0.19$ \\
\hline C $22: 2 n-6$ & $0.03 \pm 0.01$ & $0.06 \pm 0.01$ \\
\hline C $22: 3 n-3$ & $0.00 \pm 0.00$ & $0.53 \pm 0.06$ \\
\hline C $22: 5 n-3$ & $6.66 \pm 0.08$ & $5.41 \pm 0.32$ \\
\hline C $22: 6 n-3$ & $1.20 \pm 0.14$ & $3.06 \pm 0.08$ \\
\hline$\Sigma$ PUFA $^{\mathrm{D}}$ & $38.97 \pm 0.13$ & $29.13 \pm 1.72$ \\
\hline$\sum n-3$ & $16.19 \pm 0.00$ & $14.86 \pm 0.62$ \\
\hline$\sum n-6$ & $22.79 \pm 0.14$ & $14.28 \pm 1.10$ \\
\hline$n-3 / n-6$ & $0.71 \pm 0.00$ & $1.04 \pm 0.04$ \\
\hline
\end{tabular}

${ }^{\mathrm{A}}$ Average of three lots analyses. ${ }^{\mathrm{B}}$ Values reported are means $\pm \mathrm{SD}$ Cabc values for each sample with different letters in the same fraction are significantly different at $\mathrm{P}<0.05 .{ }^{\mathrm{D}}$ SFA: Saturated fatty acid, MUFA: Monounsaturated fatty acid, PUFA: Polyunsaturated fatty acid. 
The method of AOCS (1972) was employed in order to obtain the methyl esters of fatty acids by using BF3 (14\%).

Fatty acid methyl esters (FAMEs) were analyzed on a Shimadzu15-A model gas chromatograph (GC), equipped with a flame ionization detector (FID) and and a $1.8 \mathrm{~m} \times 3 \mathrm{~mm}$ internal diameter packed glass column containing 100/120 Chromosorb WAW coated with $10 \%$ SP 2330 . Injector and detector temperatures were 225 and 245 ${ }^{\circ} \mathrm{C}$, respectively. Column temperature program was $190{ }^{\circ} \mathrm{C}$ for $45 \mathrm{~min}$ then increasing for $30{ }^{\circ} \mathrm{C} / \mathrm{min}$ up to $220{ }^{\circ} \mathrm{C}$ where it was maintained for $5 \mathrm{~min}$. The total run time was $51 \mathrm{~min}$. Nitrogen used was as carrier gas $(1 \mathrm{ml} / \mathrm{min})$.

Identification of fatty acids was carried out by comparing the sample FAME peak relative retention times with those obtained for Alltech (Carolean Industrial Drive, Satate Collage, PA) standards. Results were expressed as FID response area relative percentages. Each reported result is the average value of three GC analyses. The results are offered as mean \pm SD in Table 1 .

\subsection{Statistical analysis}

Each reported result is the average value of three GC analyses. The results were given as means and standard deviations $( \pm \mathrm{SD})$. Statistical analyses were performed by using SPSS 16.0 software, and multiple comparison tests were carried out. The results were submitted to analysis of variance (ANOVA), at 0.05 significance level, using SPSS 16.0. The mean values were compared by Duncan test.

\section{RESULTS AND DISCUSSION}

Seasonal variations of total fatty acid composition of Chalcalburnus tarichi are presented in Table 1 . We found 30 fatty acids in the muscle lipids of Chalcalburnus. The highest fatty acids in the fish in two seasons were found to be 18:0, 18:2 $n-6,16: 0,16: 1 n-7,22: 6 n-3,18: 1 n-9$ and 20:4 n6.

Oleic acid (C18:1 n9) was identified as a primary monounsaturated fatty acid (MUFA) in the Chalcalburnus tarichi for two seasons. This fatty acid in the muscle tissue of Chalcalburnus was found to be at levels of $8.74 \%$ and $8.27 \%$ in winter and summer, respectively. Similarly, Haliloglu et al., (2004) found that oleic acid is the major MUFA in the muscle in the tissue of rainbow trout. Palmitoleic acid was the second most abundant MUFA (3.04-6.90\%) in the present study. The high levels of oleic, palmitoleic, and arachidonic acids had been reported as a characteristic property of Chalcalburnus tarichi (Ergun et al., 1992).

Monounsaturated fatty acids were lower than total saturated fatty acids. The ratio of total SFAs ranged from 45.36 to $50.57 \%$. In winter, a high amount of linoleic acid $(31.06 \%)$ increased the PUFA content and a high amount of linoleic acid and DHA increased the PUFA content in winter. Variations in the fatty acid composition might be related to the changes in nutritional habits of the fish (Norrobin et al., 1990). In our study, total SFA, palmitic acid and stearic acid were affected by seasonal variations in Chalcalburnus tarichi.

In this study, Chalcalburnus tarichi was rich in PUFA, especially linoleic acid, and other predominant PUFA were DHA in Chalcalburnus tarichi in winter. These results agree with $\mathrm{Ka}$ lyoncu et al., (2009) who have reported that EPA, DHA and arachidonic acid were the most abundant PUFA in zander muscle lipids in Egirdir Lake, Turkey. In our study, in Chalcalburnus tarichi, major PUFA was linoleic acid and other high levels of PUFA were DHA, and linolenic acid in summer whereas major PUFA was linoleic acid and others were linoleic acid and arachidonic acid in summer. In a previous study, DHA, EPA, AA and linoleic acid were most abundant PUFA in carp in summer and winter (Karacali et al., 2011). In our study, the total PUFA was higher than the total MUFA in Chalcalburnus tarichi in winter. Low level of DHA was decreased total PUFA in summer in Chalcalburnus tarichi. These results agree with Ozyurt et al., (2006) who has reported that PUFA is higher than the total SFA and total MUFA in Sepia officinalis.

The results in the present work indicate that the n-3/n-6 ratio of Chalcalburnus tarichi is lower in summer 0.71 , which may rise up to 1.04 in winter. Relatively high $n-3 / n-6$ ratios $(0.39-3.53)$ in different freshwater fishes were also registered by Cengiz et al., (2010). The present study indicates that Chalcalburnus tarichi are good in terms of n$3 / n-6$. The $n-3 / n-6$ ratio is a good index for comparing relative nutritional value of fish oils. An increase in the human dietary $n-3 / n-6$ fatty acid ratio is essential to help prevent coronary heart disease by reducing plasma lipids (Gokce et al., 
2004). The ratios of $n-3 / n-6$ PUFA contents were ranged from 2.71 to 9.36 in marine fish species living in Turkish waters (Tanakol et al., 1999).

\section{CONCLUSION}

In conclusion, seasonal variations and species differentiations have effected fatty acid composition of Chalcalburnus tarichi in Van Lake. This study has revealed that Chalcalburnus tarichi in the Van Lake of Turkey is a desirable item in the human diet when the levels of EPA, DHA and n$3 / n-6$ ratio are considered. The fish identified in this study was found to be good source of n-3 fatty acids.

\section{REFERENCES}

[1] AOCS, (1972): Official Methods and Recommended Practices of the American Oil Chemists Society, 2nd Ed.; American Oil Chemists Society: Champaign, Illinois.

[2] Bandarra, N. M., Batista, I., Nunes, M. L., Empis, J. M., Christie, W. W. (1997): Seasonal changes in lipid composition of Sardine (Sardina pilchardus). Journal of Food Science, 62 (1), 40-42.

[3] Cengiz, E. I., Unlu, E., Bashan, M. (2010): Fatty acid composition of total lipids in muscle tissues of nine freshwater fish from the River Tigris (Turkey). Turkısh Journal of Biology, 34, 433-438.

[4] Cunquer, J. A. (2000): Fatty acid analysis of blood plazma of patient with Alzheimer's disease, other type of dementia, and cognitive impairment. Lipids, 35, 1305-1311.

[5] Degens, F. T., Wong Ii. K., Kurtman F., Pinekk P. (1978): Geological Development of Van Lake. In: E. T. Degens and F. Kunman eds. M.T.A. Yayın No: 169. Ankara.

[6] Ergun H., Betul T., Camas H., Van Gölü İnci Kefali Balık Etlerinde Yag Asitleri Düzeyleri (1992): Y.Y.Ü. Veteriner Fakultesi Dergisi. 3 (1-2), 165-174.
[7] Folch, J., Lees, M., Stanley A. (1957): Simple method for the isolation and purification of total lipids from animal tissues. Journal of Biological Chemistry, 226, 497-509.

[8] Gokce, M. A., Tasbozan, O., Tabakoglu, S., Celik M. (2004), Seasonal variations in proximate and fatty acid compositions of female common sole (Solea solea). Food Chemistry, 88, 419-423.

[9] Haliloglu, H. I., Bayir, A., Sirkecioglu, A. N., Aras, N. M., Atamanalp, M. (2004), Comparison of fatty acid composition in some tissues of rainbow trout (Oncorhynchus mykiss) living in seawater and freshwater. Food Chemistry, 86, 55-59.

[10] Henderson, R. J., Tocher, D. R. (1987): The lipid composition and biochemistry of freshwater fish. Progress in Lipid Research, 26 (4), 281-347.

[11] Kalyoncu, L., Kissal, S., Aktumsek, A. (2009): Seasonal changes in the total fatty acid composition of Vimba, Vimba vimba tenella (Nordmann, 1840) in Egirdir Lake, Turkey, Food Chemistry, 116, 728-730.

[12] Karacali, M., Bulut, S., Konuk, M., Solak, K. (2011): Seasonal Variations in Fatty Acid Composition of Different Tissues of Mirror Carp, Cyprinus Carpio, in Orenler Dam Lake, Afyonkarahisar, Turkey. International Journal of Food Properties, 14, 1007-1017.

[13] Norrobin, M. F., Olsen, R. E., Tande, K. S. (1990): Seasonal variation in lipid class and fatty acid composition of two small copepods in Balsfjorden, northern Norway. Marine Biology, 105, 205-211.

[14] Ozyurt, G., Duysak, O., Akamca, E., Tureli, C. (2006): Seasonal changes of fatty acids of cuttlefish Sepia officinalis L. (Mollusca: Cephalopoda) in the north-eastern Mediterranean sea. Food Chemistry, 95, 382-385.

[15] Sidhu, K. S. (2003): Health benefits and potential risks related to consumption of fish or fish oil. Regul Toxicol Pharm Journal, 38 (3), 336-344.

[16] Simopoulos, A. P. (1991): Omega-3 fatty acids in health and disease and in growth and development, a review. American Journal of Clinical Nutrition, 54: 438-463.

[17] Tanakol, R., Yazici, Z, Sener, E., Sencer, E. (1999): Fatty Acid Composition of 19 Species of Fish from the Black Sea and the Marmara Sea. Lipids, 34 (3), 291-297. 